\title{
EVALUATION OF LAND CONSOLIDATION PROCESS BY RURAL STAKEHOLDERS
}

\author{
Jana Podhrázská ${ }^{1}$, Antonín Vaishar², František Toman ${ }^{3}$, Jaroslav Knotek ${ }^{4}$,

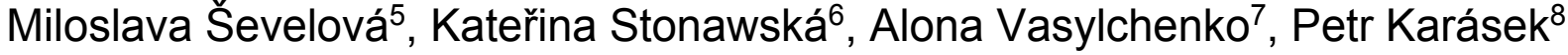

Received 11 February 2015; Accepted 17 September 2015

\begin{abstract}
The paper is focused on the current status of land consolidation in Czechia. The survey is based on a questionnaire distributed electronically to municipalities and related subjects (agricultural organizations, farmers) in areas where the land consolidation has been completed, is in progress, or is under preparation. Small farmers and municipality representatives perceive the land consolidation as a measure facilitating permeability of the landscape and protection from erosion and/or from flooding. Land consolidation is important for companies in clarification of the land ownerships and as a remedy for the landscape needs. About half of the respondents believe that the measures have rather brought benefits, whereas $41 \%$ of respondents mainly highlight problems. The negative side of the land consolidation is mostly seen in the time delays and demanding administration; agribusinesses also point out complications with land management. Nevertheless, $75 \%$ of small farmers and municipalities and $62 \%$ of agribusinesses are interested in land consolidation. The main differences between small farmers and large companies consist in their attitude to reduction of the acreage of large plots and their division by common facilities.
\end{abstract}

Key words: land consolidation, perception, quantitative research, Czechia

Souhrn: Příspěvek je zaměřen na současný stav pozemkových úprav v Česku. Výzkum vychází z dotazníkového šetření, distribuovaného elektronicky do obcí

\footnotetext{
1 Ing. Jana Podhrázská, Ph.D., Research Institute for Water and Soil Conservation Prague, 60200 Brno, Lidická 25/27; e-mail: podhrazska.jana@vumop.cz

2 Doc. RNDr. Antonín Vaishar, CSc., Mendel university in Brno, 61300 Brno, Zemědělská 1, e-mail: antonin.vaishar@mendelu.cz

${ }^{3}$ Prof. Ing. František Toman, CSc., Mendel university in Brno, 61300 Brno, Zemědělská 1, e-mail: frantisek.toman@mendelu.cz

4 JUDr. Mgr. Jaroslav Knotek, Ph.D., Mendel university in Brno, 61300 Brno, Zemědělská 1, e-mail: jaroslav.knotek@mendelu.cz

${ }^{5}$ Ing. Miloslava Ševelová, Ph.D., Mendel university in Brno, 61300 Brno, Zemědělská 1, e-mail: miloslava.sevelova@mnendelu.cz

${ }^{6}$ Ing. Kateřina Stonawská, Mendel university in Brno, 61300 Brno, Zemědělská 1, e-mail: katerina.stonawska@mze.cz

${ }^{7}$ Ing. Alona Vasylchenko, Mendel university in Brno, 61300 Brno, Zemědělská 1, e-mail: alona.vasylchenko@mendelu.cz

${ }^{8}$ Mgr. Petr Karásek, Research Institute for Water and Soil Conservation Prague, 60200 Brno, Lidická 25/27; e-mail: karasek.petr@vumop.cz
} 
a k relevantním subjektům (zemědělské organizace, rolníci) v územích, kde pozemkové úpravy proběhly, probíhají nebo jsou připravovány. Individuální rolníci a představitelé obcí vnímají pozemkové úpravy jako opatření k průchodnosti krajiny, její ochranu před erozí a záplavami. Pro podniky jsou pozemkové úpravy důležité kvưli ujasnění vlastnických otázek a obnovení potřeb krajiny. Asi polovina respondentů je přesvědčena, že opatření přinášejí spíše pozitiva, zatímco $41 \%$ $v$ nich spatřuje především problémy. Negativa, spojená s pozemkovými úpravami spočívají především $v$ časových prodlevách a náročné administrativě; $v$ prípadě podnikư také $v$ komplikacích s obhospodařováním pưdy. Nicméně $75 \%$ malých rolníků a obcí a $62 \%$ zemědělských podniků mají zájem na pozemkových úpravách. Hlavní rozdíly mezi malými rolníky a zemědělskými podniky spočívají v postoji ke snižování rozlohy pozemků a jejich rozdělování společnými zařízeními.

Klíčová slova: pozemkové úpravy, vnímání, kvantitativní výzkum, Česko

\section{Introduction}

Land consolidation represents an important instrument of rural development in the conditions of the Czech Republic. Its application consists in organization of individual plots to ensure their accessibility, interlining, or allocation and balancing the borders with the aim of rational territorial management. In this sense, property rights are settled. At the same time, environmental conditions, soil protection, water management and ecological stability of the landscape (in particular flood and erosion control measures or systems of ecological stability of landscape) are improved through the land consolidation process.

In Europe, land consolidation has to be participatory, democratic and community driven. The focus is on rural livelihood rather than on primary production of food staples. The final result consists in community renewal that is sustainable economic and political development of the whole community. It is founded on the principle of assisting the community define new uses of its resources and then reorganize its spatial components (parcels) accordingly (Riddell and Rembold, 2002).

According to Act No. 139/2002 Coll., land consolidation In Czechia should change the legal status of the land, arranging the plots spatially and functionally by blending or dividing them to ensure access to and use of land, and settling their boundaries so as to create conditions for rational management by landowners. In this context, the land status is harmonized with the property rights and related easements. At the same time, land consolidation improves environmental protection and reclamation of land, water management and the ecological stability of the landscape. The resulting landscape adjustment is used for revision of cadastral data and as a binding basis for regional planning.

The Czech (and Slovak) particularities consist in the necessity to settle the property relationships. After the WWII, the land of enemies and collaborationists was confiscated, and in the following land reform divided into plots of up to 50 ha and distributed to small farmers. During the communist regime, private land ownership was not cancelled but it was not supported. The so-called "simplified land evidence" registered land users (mainly agriculture cooperatives and state farms) rather than land owners. This led to numerous problems and uncertainties in the ownership records after 1989. Unfortunately, this situation did not improve later. Large areas of state-owned land were quickly sold out as one of the priorities of the economic transition. This resulted in the lack of free land (land mobility) for implementation of the land consolidation measures.

The whole process of land consolidation is focused on the point when the suggestion of a new arrangement of parcels is accepted, a new evidence of the real estate cadastre is created and it is possible to realize the measurements suggested. The implementation process has in fact two stages. Within the first one the land owners get an opportunity to undertake the land rights. In the second stage shared facilities are realized. The project and design phase takes $3-5$ years in average according to the size and difficulty of the project. The gradual implementation of shared facilities proceeds after the agreement with the owners and taking into account financial 
ensuring with the sources of the state budget and possibilities of EU support in different time periods.

\section{Theoretical background}

Land consolidation is understood as a comprehensive reallocation procedure of a rural area consisting of fragmented agricultural or forest holdings or their parts (Vitikainen, 2004). Land consolidation in general is a tool for improving the effectiveness of land cultivation and for supporting the rural development (Sklenička 2006). The land ownership fragmentation is an important issue for Czech farmers when non-contiguous plots of individual owners are scattered in the territory. A significant number of plots are not accessible by field roads. Also, the plot shapes and sizes are not suitable because they reflect the situation 70 years ago. These factors together with other driving forces, primarily the massive exodus of economic active people from agriculture to industry between 1950 and 1990, and the present-day mismatch between the small holding size and the large-scale agricultural machinery, drainage and irrigation systems, are at the root of the sharp distinction between the land ownership and land use (Sklenička et al., 2009).

The Land Consolidation Programme is not a specific Czech project. The measures adopted in Denmark in 1750 are considered the first land consolidation programme in Europe. Originally, land consolidation was focused on improvement of conditions for agriculture, which corresponded to rural development at that time. At present, rural development is much wider than agriculture itself. Consequently, the emphasis of land consolidation projects has shifted from a focus on restructuring agriculture to one of achieving more efficient multiple use of rural space by balancing the interests of agriculture, landscape, nature conservation, recreation and transportation, especially when the land is required for construction of major roads. The Netherlands is probably the most investigated country from this viewpoint due to the extreme land exploitation (van den Brink, 1999). The problem is also tackled by other west European countries, see e.g. van Huylenbroeck et al. (1996) in Belgium and Portugal, Rogners and Sky (1998) in Norway or Crecente et al. (2002) in Spain. The land consolidation process is also topical outside Europe: in China, India, Japan, and other parts of the world. Of course, individual countries have different historical, legal and natural conditions. However, the consequences of land fragmentation are very common. Sky (2015) is of the opinion that although the organisation and objectives of land consolidation varies from country to country, the actual process is surprisingly similar between countries. However, the particular course of land consolidation requires understanding the historical, social and legal conditions in individual countries.

The post-communist countries have to take into account a specific aspect: the interruption of the owner-based farming. A return to the (often idealized) pre-communist era showed to be problematic and in some aspects impossible. As stated by Thomas (2006): In most cases, agricultural land was privatized without any economic or environmental analysis of the newly established private farms. Van Dijk (2004) poses the question whether the "western" instruments of the land consolidation are able to solve the existing disproportions in the East. The same problem was also investigated by Hartvigsen (2014). These authors stressed the shift of land consolidation from mainly improving agricultural structures towards multi-functional projects. Pašakarnis and Maliene (2010) consider the land consolidation as a tool for creation of sustainable rural areas (in the case of Lithuania). In the Czech conditions, measures for territorial systems of ecological stability (bio-centres, bio-corridors and interaction elements) should fulfil this aim in the environmental pillar of sustainability.

The land consolidation measures should be in concordance with the European Landscape Convention (Weber 2007). Their practical implementation is a crucial issue for the land consolidation programme. Usually, only partial results are achieved, limiting the efficiency of the land consolidation process (e.g. Konečná, 2013). Apparently, the financial resources dedicated to this purpose are insufficient. Binek et al. (2011) consider the insufficient funding of the land consolidation programme as one of the biggest paradoxes of the countryside. Moreover, application of the land consolidation measures often lags behind. 
Evaluation of the land consolidation effects is not easy due to its multi-disciplinary character (Castro-Coelho et al., 2001). Bonfanti et al. (1997) highlight the improvement of land diversity in areas where the land consolidation measures were applied. Our approach is based on the evaluation of the perception of land consolidation by its users. The questionnaire survey is our main methodological instrument. The survey was completed with interviews in the field. The respondents were sought among community authorities (mostly mayors), private farmers, representatives of large (legal) firms and churches.

\section{Short history of the Czech land use and consolidation and its legal background}

The roots of modern land consolidation on the Czech territory can be found in Moravia and date from the middle of the $19^{\text {th }}$ century. They were evoked by increasing disintegration of land parcels after the cancelation of forced work in 1848 (Šilarová, 2010). Applications for land were limited by agreement of all its owners. These legal requirements were modified by the Austrian Act from 1883, which was ratified in Moravia and Silesia only. Between 1883 and 1914, land consolidation was carried out in 104 villages in Moravia (Skaloš et al., 2006). In 1939, the Act was extended to the entire territory of the Protectorate of Bohemia and Moravia.

A new statutory regulation that introduced the concept of land consolidation was adopted in 1948. In 1955, a new Government Regulation was announced with the aim to create conditions for socialist mass production and associated maximum mechanisation of agricultural activities. The real target was to create the largest possible fields. This was reflected in the limitation of ecological functions of the landscape, in opening space to erosion, disposal of scattered vegetation, and similar deleterious effects. Access to the original land parcels was no more needed, and many field roads therefore disappeared. In addition, land consolidation in the socialist period was based on user rights - not on the property rights; not on the borders between owners but on the borders between users. It means that mostly agricultural cooperatives or state farms were registered in cadastral maps. Private land parcels in cooperative use were not recorded in the maps but only mentioned in written form - in the socalled "simplified evidence" (Vitásková et al., 2006). In the period of 1948 - 1990, the land consolidation was limited to intensification and technical interventions to the landscape (disposal of scattered vegetation, systematic drainage, regulation of flows). These measures were realized under the title Economic and technical adjustments in the period 1950 - 1967 and after 1967 under the name Aggregate land consolidation. During this period the contemporary landscape has been created. In the last period before 1990 land consolidation adopted also some environmental measures. Nevertheless, the one-sided focus on intensification of land use for agriculture production predominated. In contrast with the majority of post-communist countries, where privatization of the co-operatives and state farms resulted in division of large, economically efficient units into numerous, small and economically barely viable private plots (van Dijk, 2007), in the Czech conditions the structure of large agricultural companies was mostly kept. As a rule, they cultivate land rented from small owners. No mass return to family farms has occurred. Most rural people are not any more interested in the relatively hard work with uncertain outcomes and without holidays. Outbuildings, which earlier were part of rural houses, have disappeared or were rebuilt, the houses have acquired urban character. Although the parcels are extremely small, they are still cultivated as large tracts of land. Sklenička et al. (2014) called this feature Farmland Rental Paradox.

A new period started in 1991 when District Land Offices were appointed, with additional changes in 2013 when the State Land Office was established. Respect for the land property has been renewed. Currently valid legislation was adopted in 2002. During the development of land consolidation, its methods and tools were developed step by step, including different landscape metrics (Tlapáková et al., 2013).

The present focus of the land consolidation lies on the following priorities:

a) Clarification and revision of the ownerships through renewal of cadastral records

b) Implementation of common facilities by means of

- ensuring access to individual plots 
- application of erosion and flood control measures

- application of ecological stability measures.

The land required for establishment of the common facilities should first be covered by stateowned land, then by municipal land, and finally by private land (under well-defined conditions). At the beginning of the transformation, the state owned about one million hectares of land. However, a large part of this land was sold without any concept. Consequently, there is often not enough land to ensure the shared facilities - particularly in cases when municipalities acted similarly as the state (Filip and Podhrázská, 2010).

Land consolidation in Czechia has to cope with problems which are unique in Europe: necessity of cadastral restoration and necessity of an improvement of the agricultural landscape at the same time. Individual methodological procedures as well as their technical support underwent a complicated development. The land consolidation is finished on about $14 \%$ of cadastres at the present time.

\section{Methodology and Data}

A survey research was the main method of the study. The questionnaire was mainly focused on the following issues: understanding the aim and course of the land consolidation process, land consolidation pros and cons, general opinion on the land consolidation process. The following groups of respondents were addressed: representatives of local administration (mostly mayors of rural municipalities), land owners (farmers and representatives of agricultural legal entities), and other participants such as church representatives. Three groups of municipalities were selected: communities with completed land consolidation process (having experience with its course and results), communities with ongoing land consolidation (having experience with its course) and communities with land consolidation under preparation (with little or no experience). The selected municipalities are dispersed throughout all administrative regions of the Czech Republic. Different landscape types were considered: lowlands, highlands, suburban zones, borderland, and inner periphery. The general database of land consolidation is managed by the Ministry of Agriculture (Fig. 1).

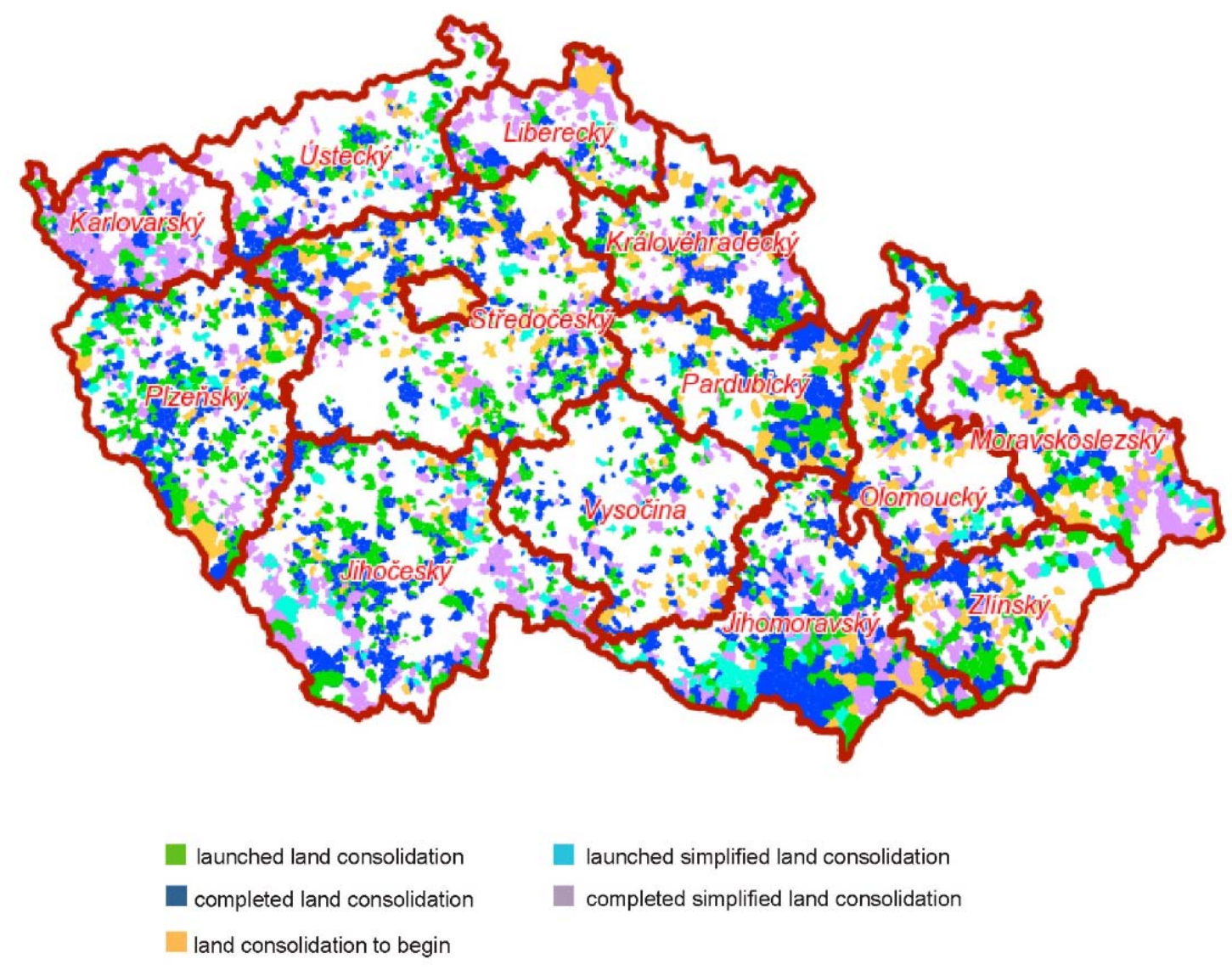

Fig 1. Land consolidation in the Czech Republic. Source: Praha: Ministry of Agriculture. 
The Survio software was used for the distribution and primary processing of the questionnaires. Electronic distribution has the following advantages: low expenses, easy and rapid operation, and primary processing of the results. Low return of responses is the main disadvantage because the only motivation of the respondents is their interest in improving the situation. In addition, people who are less familiar with electronic communication (e.g. old farmers with lower education level) cannot participate ${ }^{9}$. The questionnaire was distributed in the following scheme: municipalities with completed land consolidation [10], municipalities with ongoing land consolidation [10], and municipalities with land consolidation under preparation [10] from each region (NUTS 3) of the Czech Republic (except for Prague). Each district (NUTS 4) was represented. The municipalities represented various landscape types: lowlands, highlands, suburban zones, inner periphery, borderland (Fig. 2).

Two types of questionnaires were distributed: one for small farmers, municipalities and individual subjects, and one for large companies representing decisive producers in the primary sector.

Altogether 749 respondents were addressed. Of them, 235 subjects downloaded the questionnaire and 73 completed it. This represents $9.8 \%$ return. Of these, $74 \%$ were male, $55 \%$ achieved university degree, $47 \%$ were employed in the primary sector and $35 \%$ in service trades. Of the respondents, $36 \%$ own $20-50$ ha of land in their municipality, $34 \%$ own larger plots, $26 \%$ smaller ones, and $4 \%$ of respondents do not own any land in the respective cadastral area. Of all the respondents, $73 \%$ farm the land, $48 \%$ rent it (some of them partly farm, partly rent the land), and in $3 \%$ of cases the land lies fallow.

\section{Results and Discussion}

As a main achievement of land consolidation, most respondents emphasize protection from erosion and remedy of the landscape needs (however, many respondents have no idea about the meaning of landscape needs). Clarification of the ownership seems to be the most problematic issue. The majority of respondents do not believe in the effectiveness of land consolidation in the field of protection from floods (see Fig.2).

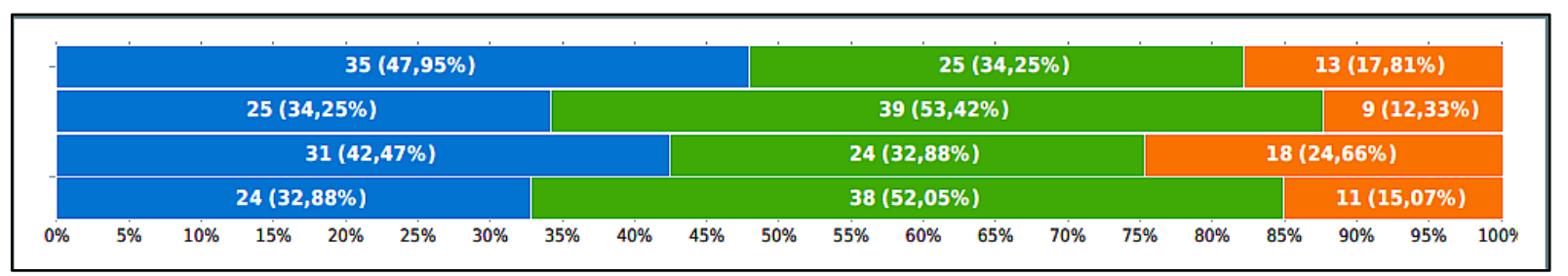

Fig 2. Frequency of responses to the question about the achievements of land consolidation in the respective municipality: protection from erosion (1 $1^{\text {st }}$ line), protection from floods $\left(2^{\text {nd }}\right.$ line), landscape needs $\left(3^{\text {rd }}\right.$ line), ownership (4th line) - yes/blue, no/green, no opinion/orange. Source: own questionnaires.

Regarding the general evaluation of the land consolidation, $41 \%$ of respondents are of the opinion that it brought about both improvements and problems, $29 \%$ have no personal opinion, and $26 \%$ see positive preliminary impacts whereas $4 \%$ highlight problems.

The respondents were asked about their opinion on specific benefits of the landscape consolidation in their municipalities. They were allowed to select more answers (Fig. 3). Their answers show that the landscape consolidation is perceived in connection with the ownership at the first place. The second most frequent response concerned permissiveness of the landscape and thus better land management, whereas ecological aims were generally underestimated. However, some respondents point out the differences between land consolidation projects and their implementation.

\footnotetext{
${ }^{9}$ According to the Czech Statistical Office, 65\% of the Czech households were connected to high-speed Internet in 2012 - in rural areas slightly less than in the cities. The main reasons of no connection are: households do not need the connection, nobody in the household is able to use the Internet, the price of the connection is too high.
} 
Among problems associated with landscape consolidation, the respondents stress time delays $(49 \%)$ and extensive administration (31\%). In contrast, $22 \%$ of participants did not associate land consolidation with any problems. $75 \%$ of respondents presume that land consolidation is interesting for urban populations, $8 \%$ are of the opposite opinion, and $17 \%$ do not have any opinion.

Evaluation of land management was determined using answers to the following set of questions. According to the respondents, local citizens are owners of the decisive share of agricultural companies. Most agricultural companies do not participate in the development of the respective municipality (56\% of answers). In $65 \%$ of cases the respondents are of the opinion that there exist conditions for ecological agriculture. $60 \%$ of respondents believe that farmers apply the measures aimed at reducing erosion such as modified type of tillage and no row seeding. $74 \%$ of respondents agree with restoration of borders and $70 \%$ approve reduction of the acreage of large tracts.

Protection of the landscape, wildlife and cultural heritage is a concern for $56 \%$ of respondents. In $56 \%$ of cases this protection is perceived positively or rather positively, and in $13 \%$ of cases negatively or rather negatively in relation to the business in productive sectors (the rest of respondents expressed a neutral standpoint). Concerning tourism development, the protection is perceived positively and rather positively in $59 \%$ of cases, and negatively and rather negatively in $10 \%$ of cases.

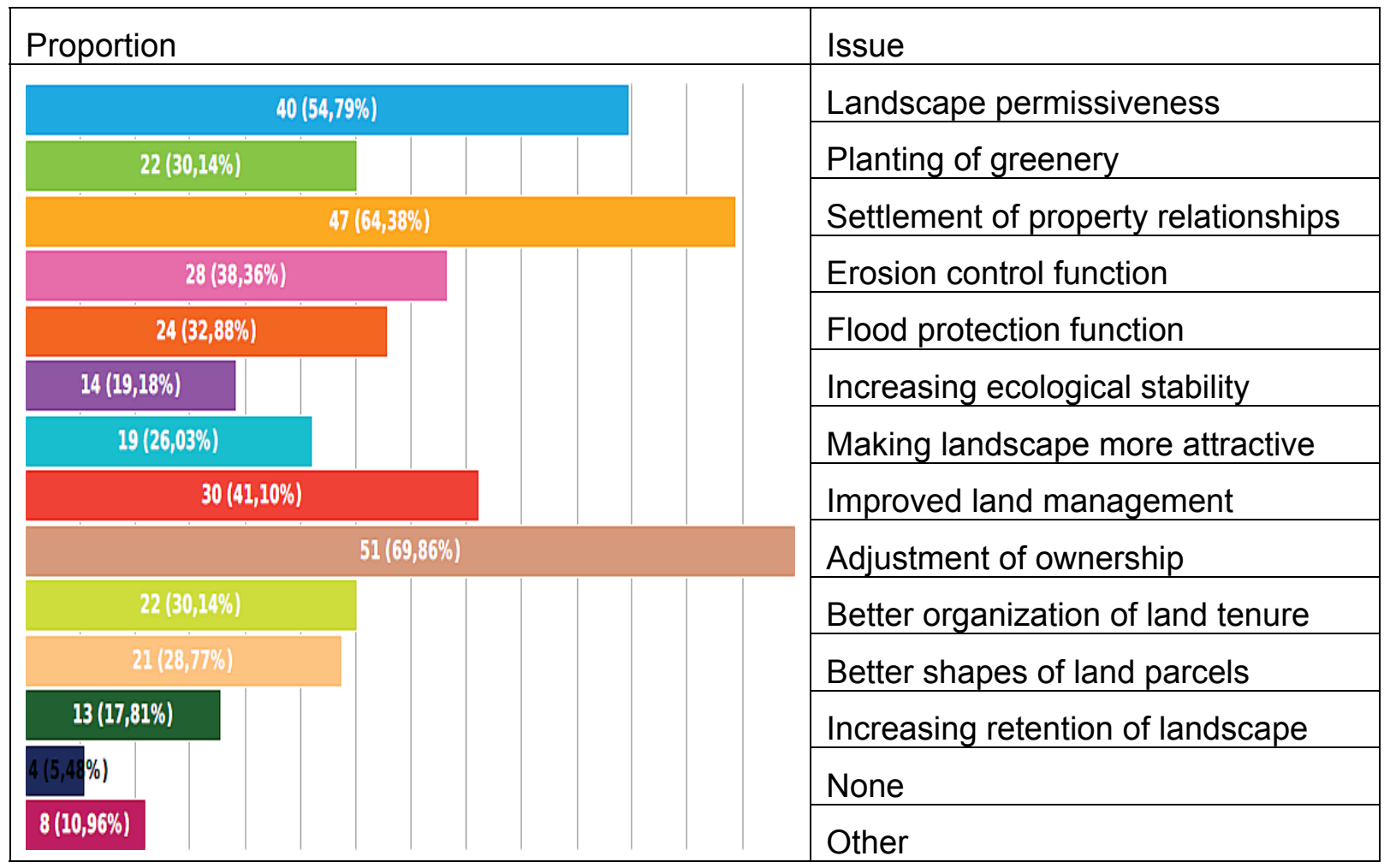

Fig 3. Opinions of respondents about specific benefits of land consolidation for their municipalities. Source: own questionnaires.

The perception of land consolidation can be related to the expected future functions of individual municipalities. Multifunctional development (housing, service trades, jobs) is preferred by $66 \%$ of respondents, $18 \%$ prefer the primary sector (agriculture, forestry) and $11 \%$ respondents should direct their municipality to the residential function. Surprisingly, the often recommended branches such as tourism and production of energy from renewable sources were indicated by one respondent each.

Economic stability is most frequently perceived as the main value of the municipality $(23 \%)$. It is followed by natural values $(22 \%)$, cultural heritage $(16 \%)$, environmental values $(12 \%)$ and 
economic development (6\%). About $21 \%$ of respondents are of the opinion that their municipality does not have any special value.

The respondents were also asked to what aim they would devote public funds if they had the possibility to decide (Fig. 4). In their answers the respondents preferred infrastructural improvements, both technical (roads, bridges, water supplies, sewage systems, water treatment stations, gasification) and social (schools, physicians, shops, other services). The municipalities wish to approach the urban way of life, often contrary to their real economic possibilities. Surprisingly, the care for public spaces occupies the next position. It is interesting that nature preservation and support of cultural, sport and social life are more important for the respondents than support of the economic development. The respondents probably understand that economic development is a matter of private activities similarly as housing. Support of public transport takes the last position, despite frequent complaints. The respondents may have resigned, or the situation is in fact better than it seems.

\begin{tabular}{|c|c|}
\hline \multicolumn{2}{|l|}{ Proportion } \\
\hline $26(35,62 \%)$ & Support of economic development \\
\hline \multicolumn{2}{|r|}{ Technical infrastructure } \\
\hline $16(21,92 \%)$ & Housing \\
\hline \multicolumn{2}{|r|}{ Culture sport associations } \\
\hline Imnrovement of nublic snaces & Improvement of public spaces \\
\hline \multicolumn{2}{|r|}{ Nature preservation } \\
\hline $9(12,33 \%)$ & Support of public transport \\
\hline \multicolumn{2}{|r|}{ Social infrastructure } \\
\hline
\end{tabular}

Fig 4. Distribution of public funds according to the respondents. Source: own questionnaires.

The questionnaire for large companies was sent to 487 subjects. Of them, 144 downloaded the document and 50 responded to the questionnaire. The return was thus slightly higher than in the case of individuals $-10.3 \%$. About $70 \%$ of respondents were male. They represented agribusinesses managing up to 500 ha in seven cases, 501 - 1,500 ha in 19 cases, 1,501 2,500 ha in 13 cases $2,501-3,500$ ha in seven cases, and larger subjects in four cases. It is interesting that only $14 \%$ of agricultural land was farmed by companies owning the land, whereas $84 \%$ of land was rented from small owners.

The business leaders appreciate clarification of the ownerships (92\%), needs of the landscape $(50 \%)$, protection from erosion $(26 \%)$, and protection from floods $(12 \%)$. They evaluated landscape consolidation in a neutral way (resulting both in improvements and problems), and $26 \%$ of them see rather improvements in contrast to $24 \%$ stressing problems.

Similarly as farmers and municipalities, the business leaders also expect mainly clarification of the ownership from the land consolidation (Fig. 5). Landscape permissiveness, improved land management, and better shapes of land parcels are among the next relatively frequent expectations. On the other hand, objectives not directly connected with agricultural production (aims of the ecological and social nature) are almost out of the interest of the businesses, which is understandable but not positive. 


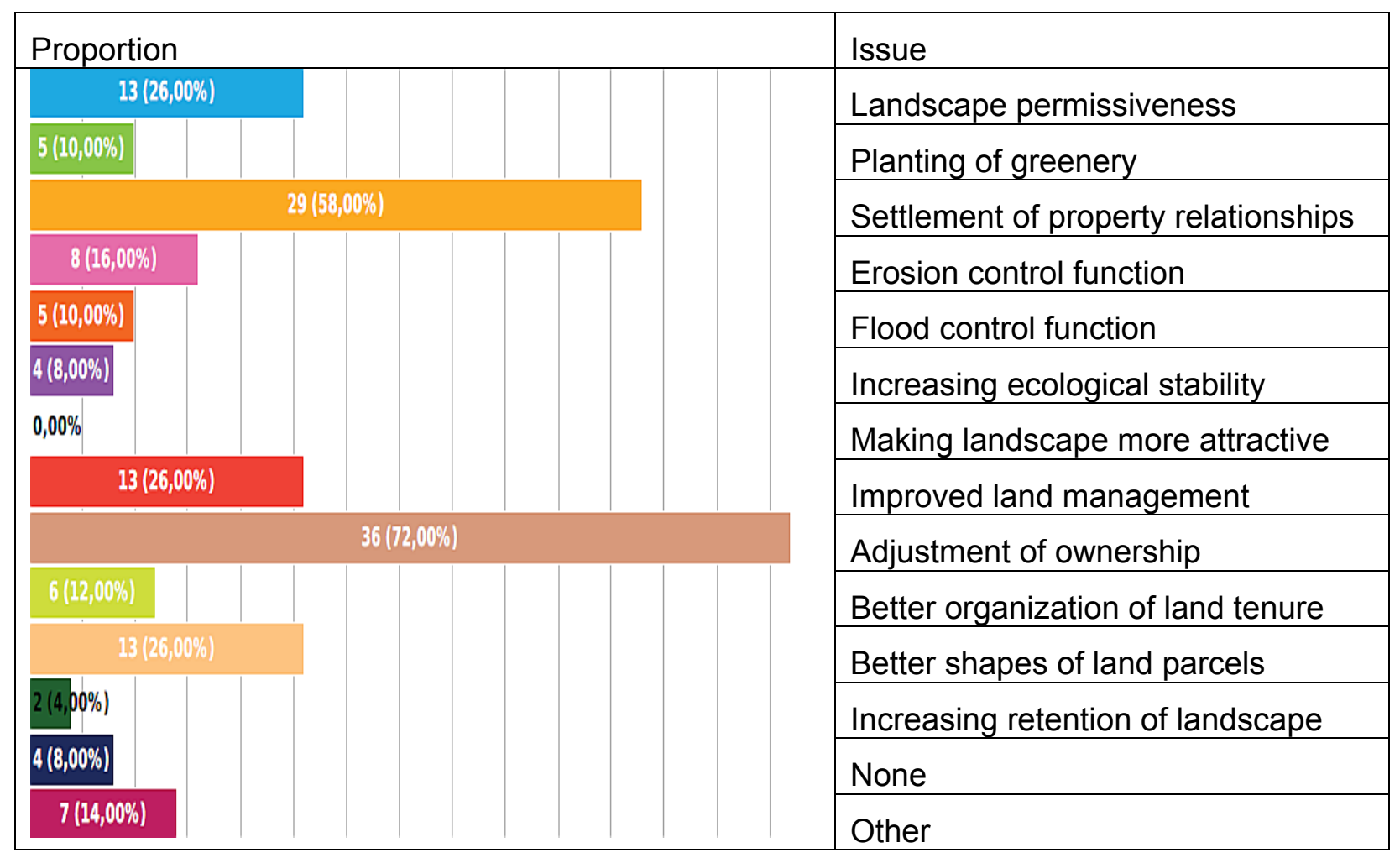

Fig 5. Opinions of business leaders about specific benefits of land consolidation for their municipalities. Source: own questionnaires.

The business leaders complain about the following issues: problems with land management $(34 \%)$, heavy administration (30\%), time delays $(28 \%)$. On the other hand, $12 \%$ of respondents express their disagreement with planting of new greenery. No problems are perceived by $18 \%$ of respondents. Nevertheless, $62 \%$ of leaders are interested in land consolidation, and $74 \%$ of them state that their companies participate in the development of municipalities and $98 \%$ apply erosion control practices. On the other hand, $48 \%$ of them disagree with restoration of borders (and additional $28 \%$ agree only under particular conditions), while $54 \%$ disagree with reduction of large tracts (additional 34\% agree under defined conditions). Landscape, nature and heritage protection is perceived by $40 \%$ of companies positively or rather positively, by $36 \%$ in a neutral way and by $24 \%$ negatively or rather negatively. In contrast to farmers and municipalities, the business leaders prefer agricultural or forestry function of the municipalities $(68 \%)$ over multifunctional development (22\%). Among the values of the municipalities, business leaders most appreciated economic stability (52\%) and natural values (44\%). They prefer economic growth $(20 \%)$ to small farmers and municipalities. $60 \%$ of businesses would like to spend public funds for the support of economic development, $40 \%$ for construction of technical infrastructure and $32 \%$ for landscape protection. Social infrastructure is outside their interest.

Similar surveys have been conducted recently. Karásek et al. (2014) evaluated the questionnaire distributed to rural schools and municipalities. In this study only ca $22 \%$ of respondents believed that land consolidation treats the problems of landscape adequately. Kupidura et al. (2014) also added visitors to their set of respondents. These authors highlighted the question of aesthetic values of the landscape that should change the traditional pattern of the utilitarian approach to the landscape evaluation by farmers. They concluded that optimally shaped landscape could contribute to attracting visitors and obtaining financial support under EU programmes. Muchová and Petrovič (2014) also mentioned improvement of the landscape aesthetics through the land consolidation measures, thus increasing its attractiveness. According to the present study, only ca 19 , i.e. $16 \%$ respondents share this view.

Miranda et al. (2006) used the EU methodology to state very generally that land consolidation measures have had positive effects in Galicia (Spain) during the last 50 years. They asked the following questions: 
a) Has land consolidation influenced the property structure in rural areas?

b) Has land consolidation influenced land usage?

c) Has land consolidation intensified agricultural and forestry production?

d) Has land consolidation reduced emigration from rural areas?

e) Is paralysis of land consolidation plans dependent on local socio-economic factors, and if so, on which?

Let us be inspired by this set of questions. Land consolidation in Czechia influenced land usage only partially, as mentioned by Sklenička et al. (2014), due to the fact that about $80 \%$ of agricultural land is rented. On the contrary, land consolidation enabled creation of plots with optimal shape and area, together with property adjustment, and enabled development of the land market. By establishment of common facilities, especially field roads, agricultural production has more opportunities to be intensified (optimised) (Filip and Podhrázská, 2010).

Reduction of potential emigration from rural areas is not among the goals of the land consolidation in the Czech conditions. The proportion of the economically active people employed in agriculture in municipalities with less than 2,000 inhabitants is $11.1 \%$ (2011). Many of them are employees of legal entities. Thus, the migration trends between urban and rural space depend much more on such processes as suburbanization, deurbanization, reurbanization, etc. The Czech rural areas have been gaining population in the last decade. Rural immigrants look for a quiet milieu, proximity to nature, cheaper living costs. Under such conditions, the land consolidation serves very indirectly as a general tool of rural development, especially in the field of environmental measures.

\section{Conclusion}

Small farmers and representatives of municipalities perceive the land consolidation measures as a tool for clarification of owner relationships. Among the values of municipalities, the landscape permissiveness (more field roads) seems to be most important, similarly as erosion and/or flood control. Land consolidation is important for agribusinesses as a tool for clarification of ownerships and remedy to the needs of the landscape. About half of the respondents believe that land consolidation rather brought benefits.

The main differences in opinions between small farmers and large companies consist their attitude towards restoration of borders accompanied by reduction of the acreage of large plots and their division by field roads. Small farmers mostly agree with such measures. On the other hand, about half of the companies do not agree - apparently because of the technology used.

The negative sides of the land consolidation measures are mostly seen in the time delays and demanding administration; in the case of companies also in complications with land management. The standard time of the land consolidation process represents three to five years. However, some years must be added between the expression of the municipality's will and the start of the process, together with an undefined time between completion of the project and establishment of the common facilities. At present, many projects are prepared but not yet implemented. About $14 \%$ of the territory is covered by land consolidation projects. The duration of the design stage take several years. Nevertheless, in general all the respondents are interested in the land consolidation.

In reality, the owners and users agree with the land consolidation measures in general, but disagree at the moment when the specific activity concerns their land or other interests. This is the typical "not in my backyard" conflict (Wexler, 1996).

\section{Acknowledgement}

This work was supported by project "Benefits of Land Consolidation to the Development of a Region" No. TD 020241V001 of the Technological Agency of the Czech Republic, programme OMEGA. 
[1] Binek, J., Svobodová, H., Chabičovská, K., Holeček, J., Galvasová, I. \& Martének, J. (2011). Synergie ve venkovském prostoru. Brno: GaREP.

[2] Bonfanti, P., Fregonese, A. \& Sigura, M. (1997). Landscape analysis in areas affected by land consolidation. Landscape and Urban Planning 37(1-2), 91-98. Doi: 10.1016/S01692046(96)00373-8.

[3] Brink, van den, A. (1999). Sustainable development and land consolidation. In. DixonGough, R. W., ed., Land Reform and Sustainable Development (pp. 61-68), Aldershot: Ashgate.

[4] Castro-Coelho, J., Aguiar Pinto, P. \& Mira da Silva, L. (2001). A systems approach for the estimation of the effects of land consolidation projects (LCPs): a model and its application. Agricultural Systems 68(3), 179-195.

[5] Crecente, R., Alvarez, C. \& Fra, U. (2002). Economic, social and environmental impact of land consolidation in Galicia. Land Use Policy 19(2), 135-147.

[6] Dijk van, T. (2004). Land consolidation as Central Europe's panacea reassessed. In Symposium on Modern Land Consolidation. Københaven: International Federation of Surveyors.

[7] Dijk van, T. (2007): Complications for traditional land consolidation in Central Europe. GeoForum 38(3), 505-511. Doi: 10.1016/j.geoforum.2006.11.010.

[8] Filip, R. \& Podhrázská, J. (2010). Land need assessment for the project of common facilities and its dependence. Acta Universitatis Agriculturae et Silviculturae Mendelianae Brunensis 58(5), 97-105. (in Czech)

[9] Hartvigsen, M. (2014). Land mobility in Central and Eastern Europe land consolidation context. Nordic Journal of Surveying and Real Estate Research 10(1), 23-46.

[10] Huylenbroeck van, G., Castro Coelho, J. \& Pinto, P. A. (1996). Evaluation of land consolidation projects (LCPs): a multidisciplinary approach. Journal of Rural Studies 12(3), 297-310.

[11] Karásek, P., Stejskalová, D. \& Ulčák, Z. (2014). Analysis of Rural Social Aspects in the Context of Land Consolidations and Land Use Planning, the Case Study, Czech Republic. Acta Universitatis Agriculturae et Silviculturae Mendelianae Brunensis 62(3), 507-515.

[12] Konečná, J. (2013). Hodnocení realizací protierozních a vodohospodářských opatření $v$ pozemkových úpravách [doctoral thesis]. Brno: Mendel University in Brno.

[13] Kupidura, A., Łuczewski, M., Home, R. \& Kupidura, P. (2014). Public perceptions of rural landscape in land consolidation procedures in Poland. Land Use Policy 39, 313-319. Doi: 10.1016/j.landusepol.2014.02.005.

[14] Lisec, A., Primožič, T., Ferlan, M., Šumrada, R. \& Drobne, S. (2014). Land owners' perception of land consolidation and their satisfaction with the results - Slovenian experiences. Land Use Policy 3, 550-563. Doi: 10.1016/j.landusepol.2014.01.003.

[15] Miranda, D., Crecente, R. \& Flor Alvarez, M. (2006). Land consolidation in inland rural Galicia, N. W. Spain since 1950: An example of the foundation and use of questions, criteria and indicators for evaluation of rural development policies. Land Use Policy 23(4), 511-520. Doi: 10.1016/j.landusepol.2005.05.003.

[16] Muchová, Z. \& Petrovič, F. (2014). Impact of land consolidation on the visual characteristics (scenery) of a landscape. Journal of Central European Agriculture 15(1), 7685. Doi: 10.5513/JCEA01/15.1.1414. 
[17] Pašakarnis, G. \& Maliene, V. (2010). Towards sustainable development in Central and Eastern Europe: applying land consolidation. Land Use Policy 27(2), 545-549. Doi: 10.1016/j.landusepol.2009.07.008.

[18] Pašakarnis, G., Morley, D. \& Maliené, V. (2013). Rural development and challenges establishing sustainable land use in Eastern European countries. Land Use Policy 30(1), 703-710. Doi: 10.1016/j.landusepol.2012.05.011.

[19] Riddell, J. \& Rembold, F. (2002). Farm land rationalization and land consolidation: strategies for multifunctional use of rural space in Eastern and Central Europe. International Symposium on Land Fragmentation and Land Consolidation in CEEC: A Gate Towards Sustainable Rural Development in the New Millennium, München: FAO Regional Office for Europe and Central Asia.

[20] Rogners, J. \& Sky, P. K. (1998). Mediation in the Norwegian land consolidation courts. Madison: University of Wisconsin.

[21] Sabates-Wheeler, R. (2002). Consolidation initiatives after land reform. Responses to multiple dimensions of land fragmentation in eastern European agriculture. Journal of International Development 14(7), 1005-1018. Doi: 10.1002/jid.905.

[22] Šilarová, K. (2010). Pozemkové úpravy [bachelor thesis]. Brno: Masaryk University.

[23] Skaloš, J., Molnárová, K. \& Kottová, P. (2012). Land reforms reflected in the farming landscape in East Bohemia and Southern Sweden - two faces of modernisation. Applied Geography 35(1-2), 114-123. Doi: 10.1016/j.apgeog.2012.06.003.

[24] Sklenička, P. (2006). Applying evaluation criteria for the land consolidation effect to three contrasting study areas in the Czech Republic. Land Use Policy 23(4), 502-510. Doi: 10.1016/j.landusepol.2005.03.001.

[25] Sklenička, P., Hladík, J., Střeleček, F., Kottová, B., Lososová, J., Číhal, L. \& Šálek, M. (2009). Historical, environmental and socio-economic driving forces on land ownership fragmentation, the land consolidation effect and the project costs. Agricultural Economics Czech 55(12), 571-582.

[26] Sklenička, P., Janovská, V., Šálek, M., Vlasák, J. \& Molnárová, K. (2014). The farmland rental paradox: Extreme land ownership fragmentation as a new form of land degradation. Land Use Policy 38, 587-593. Doi: 10.1016/j.landusepol.2014.01.006.

[27] Sky, P. K. (2015). Land consolidation in Norway in an international perspective. Spanish Journal of Rural Development 6(1-2), 81-90.

[28] Thomas, J. (2006). Property rights, land fragmentation and the emerging structure of agriculture in Central and Eastern European countries. Journal of Agricultural and Development Economics 3(2), 225-275.

[29] Tlapáková, K., Stejskalová, D., Karásek, P. \& Podhrázská, J. (2013). Landscape metric as a tool for evaluation of landscape structure - case study Hustopeče. European Countryside 5(1), 52-70. Doi: 10.2478/euco-2013-0004.

[30] Vitásková, J., Toman, F. \& Št'astná, M. (2006). Development of the land cadastre in Czechia and the current issue of transition of simplified land records into maps. Acta Universitatis Agriculturae et Silviculturae Mendelianae Brunensis 54(2), 193-202. (in Czech)

[31] Vitikainen, A. (2004). An overwiev of land consolidation in Europe. Nordic Journal of Surveying and and Real Estate Research 1(1), 25-44.

[32] Weber, M. (2007). Evropská úmluva o krajině a možnosti její implementace v oblasti koncepčních a plánovacích nástrojů pro realizaci krajinných politik. Urbanismus a územní rozvoj 10(1), 42-46.

[33] Wexler, M. N. (1996). A sociological framing of the NIMBY (not-in-my-backyard) syndrome. International Review of Modern Sociology 26(1), 91-110. 